\title{
International collaborative study by in vitro bioassays of the first International Standard for porcine inhibin
}

\author{
R. E. Gaines Das ${ }^{1}$, M. Rose ${ }^{2}$ and J. M. Zanelli ${ }^{2}$ \\ Division of ${ }^{1}$ Informatics and ${ }^{2}$ Endocrinology, WHO International Laboratory for Biological \\ Standards, National Institute for Biological Standards and Control, Blanche Lane, South Mimms, \\ Potters Bar, Hertfordshire EN6 $3 Q G, U K$
}

\begin{abstract}
Summary. A lyophilized preparation of inhibin from porcine ovarian follicular fluid, ampoule code $86 / 690$, was made internationally available as a research standard for in vitro bioassays in 1987 . A study involving ten participants in eight countries assessed the stability and suitability of this research standard to serve as an international standard. Each of the participants used in vitro assays, the majority of which depended upon the inhibition of release of follicle-stimulating hormone from dispersed rat anterior pituitary cells. The research standard $86 / 690$ was compared with coded ampoules of $86 / 690$ stored under conditions of accelerated thermal degradation and with inhibins from different species. Intra- and interlaboratory variation for estimates of potency of a coded duplicate ampoule of the research standard provided the basis for comparisons of non-identical inhibins, but the fourfold variability of potency estimates for identical ampoules was such that no conclusions about the differences seen for non-identical inhibins could be made. Predictions of stability from consensus estimates of potency of ampoules that have undergone accelerated thermal degradation indicated that the research standard had satisfactory stability. On the basis of this study, the research standard $86 / 690$ was deemed sufficiently stable and suitable to serve as a standard for in vitro bioassays and was established by the World Health Organization Expert Committee on Biological Standardization as the First International Standard for Porcine Inhibin. The possible presence, in biological extracts (standard or sample), of other bioactive proteins, such as activin and follistatin, complicates the quantitative interpretation of bioassay data. A standard of highly purified human inhibin is now required as a standard for immunoassays used for clinical research purposes; sufficient quantities of recombinant human inhibins have recently been donated for ampouling and evaluation by bio- and immunoassay in the subsequent phase of the standardization of inhibins.
\end{abstract}

Keywords: inhibin; in vitro bioassay; international standard; pig

\section{Introduction}

Inhibin is classically defined as a non-steroidal hormone produced by the gonads, which has an inhibitory effect upon the secretion of follicle-stimulating hormone (FSH) by the pituitary. The concept of an 'inhibin' was postulated some 70 years ago (McCullagh, 1932), but the biological entity, a glycoprotein hormone, was first isolated from bovine follicular fluid and characterized in 1985 (Robertson et al., 1985). The cloning of the complementary DNA and the full structure of the bovine and human molecules was achieved shortly afterwards (Forage et al., 1986; Mason et al., 1986; Stewart et al., 1987). It is known that inhibin is a heterodimer consisting of $\alpha$ and $\beta$ subunits and has structural homology to other bioactive glycoproteins, including Müllerian Inhibitory Substance, transforming growth factor $\beta$, activin, erythroid-differentiating factor and bone 
morphogenic proteins, suggesting that inhibin has paracrine or autocrine as well as endocrine function (for reviews, see de Jong et al., 1990; de Kretser, 1990; Ling et al., 1990).

The physiological endocrine role of inhibin in the male and female of various species, including man, has been a subject of active research, although in vivo experimental studies, including those on the potential use of inhibin as a male antifertility agent, have been hampered by the lack of supplies of inhibin.

Throughout the past 20 years, studies on inhibin-like bioactivity isolated from tissue such as testis, ovary, placenta (or, more recently, human inhibin produced by recombinant technology) depended upon in vitro biological test systems in which the inhibition of pituitary cell FSH could be detected and measured. The need for an ampouled, stable reference material to be widely available and to serve as a research standard for such in vitro bioassays was identified in 1984 by the World Health Organization (WHO) Special Programme of Research, Development and Research Training in Human Reproduction (Geneva). The National Institutes of Health (NIH) Contraceptive Development Branch (Bethesda, MD) arranged to provide a sufficient quantity of an extract of porcine follicular fluid and the first research standard for porcine inhibin was ampouled at the National Institute for Biological Standards and Control (NIBSC) in 1986.

Provisional assessment of this research standard, ampoule code $86 / 690$, was carried out as described elsewhere (Waites et al., 1987) and the material was made available on an international basis for research in 1987.

The international collaborative study reported here was initiated in 1988 to assess the stability and suitability of the WHO/NIH research standard of partially purified porcine ovarian follicular fluid inhibin (code 86/690) to serve as an International Standard and to compare it with ampouled samples of inhibins from bovine and human follicular fluid and with ovine rete testes fluid, which were representative of a wide variety of working standards used in various bioassay systems in vitro. It was hoped that the information obtained from the study would also permit an independent assessment of the variability of the in vitro bioassay systems in widest use for inhibins.

\section{Materials and Methods}

\section{First International Standard for Porcine Inhibin}

Bulk material for $86 / 690$. The bulk material consisted of $40 \mathrm{mg}$ of an extract of porcine follicular fluid, batch number WLG-4-55B, which had been prepared by procedures similar to those described by Gordon et al. (1986). The inhibin was partially purified from charcoal-treated porcine follicular fluid by precipitation with acetone and by chromatography on Sephacryl S200 and Sephadex G75. The inhibin potency of WLG-4-55B was assessed in an in vitro rat pituitary cell assay which measured basal release of FSH. Using this assay system, the dose of WLG-4-55B which gave inhibition of $50 \%$ of FSH release was estimated to be $55 \mathrm{ng}$ (by W. L. Gordon at Houston) and $62 \mathrm{ng}$ (by F. H. de Jong at Rotterdam). The purity of this preparation was estimated to be about $1-3 \%(\mathrm{w} / \mathrm{w})$ (Waites et al., 1987). In 1986, it was considered that FSH-stimulating proteins (activins) were the bioactive agents most likely to be present in the extract and to interfer in the pituitary cell assay. However, as reported by Waites et al. (1987), published work from another group (Vale et al., 1986) had shown that the molar ratio of inhibin:activin which resulted in interference was 10:1, and no activin activity was found when the preparation WLG-4-55B was fractionated by high-performance liquid chromatography.

Distribution into ampoules. In November $1986,37.9 \mathrm{mg}$ of WLG-4-55B was added to $38 \mathrm{ml}$ of a diluent consisting of acetic acid $\left(1 \mathrm{mmol}^{-1}\right)$ containing $0 \cdot 1 \%$ purified peptidase-free human plasma albumin (Lister Institute, Elstree, UK), $0.5 \%$ trehalose and $1.5 \mathrm{mmol}$ sodium chloride $1^{-1}$ at $\mathrm{pH} 4.5$. Glacial acetic acid was added drop by drop to a final concentration of about $400 \mathrm{mmol}^{-1}$. The resulting opalescent solution was clarified using a $0.45 \mu \mathrm{m}$ filter (Millex HA; Millipore Watford, UK) and further diluted with the original diluent to give a concentration of $20 \mu \mathrm{g}$ of WLG-4-55B $\mathrm{g}^{-1}$ of solution. The solution was then distributed into ampoules coded $86 / 690$ (filling volume $1.0 \mathrm{ml}$ ). The mean weight of solution in each of 32 weighed ampoules was $1.01 \mathrm{~g}$ with a range of $0.27 \%$ of the mean. The ampoule contents were freeze-dried, secondarily desiccated and sealed under nitrogen according to procedures recommended by the WHO Expert Committee on Biological Standardization (WHO ECBS, 1990).

Preliminary assessment of ampoule contents. The potencies of the bulk WLG-4-55B and the ampoule contents of $86 / 690$ were estimated in terms of the NIH folliculostatin reference preparation FS RP 119-6-4, ovine testicular lymph protein (oTLP) and of in-house standards of bovine follicular fluid. Rat pituitary cell assays measuring FSH release 
and cell content were used. The data indicated that most of the activity of the bulk had been retained during the distribution into ampoules.

Although WLG-4-55B exhibited some protease activity when tested with a chromogenic substrate (Caygill, 1977), this was reduced to about half, a negligible level, when albumin was added to the ampoules.

Pending international collaborative study and in the interest of making a research standard available as soon as possible, it was decided by a WHO working group (consisting of J. K. Findlay, F. H. de Jong, D. M. Robertson and P. L. Storring) that $86 / 690$ be assigned a value of 2000 units ampoule $^{-1}$ (Waites et al., 1987). This value was assigned on the basis that 1 unit is about $10 \mathrm{ng}$ of WLG-4-55B, taking into account that the working range of most in vitro bioassays is between 5 and $200 \mathrm{ng}$.

Degradation samples of 86/690. Coded 'degradation samples' consisted of (C) an ampoule of 86/690 stored continuously at $-20^{\circ} \mathrm{C}$ in the dark and relabelled, i.e. a coded duplicate of $86 / 690$; (E) an ampoule of $86 / 690$ that had been stored at $4^{\circ} \mathrm{C}$ for 15 months (referred to as $\mathrm{E}\left(+4^{\circ}\right)$ ); (A) an ampoule of $86 / 690$ that had been stored at $20^{\circ} \mathrm{C}$ for 15 months $\left(\mathrm{A}\left(+20^{\circ}\right)\right.$ ); and (D) an ampoule of $86 / 690$ that had been stored at $37^{\circ} \mathrm{C}$ for 15 months $\left(\mathrm{D}\left(+37^{\circ}\right)\right.$ ). Sample C, the coded duplicate, provided an independent determination of intra-assay variation based on its direct comparison with $86 / 690$ and also served as a 'base line' sample for the thermally degraded samples since it was expected to be handled in the same way as $A\left(+20^{\circ}\right), D\left(+37^{\circ}\right)$ and $E\left(+4^{\circ}\right)$.

\section{Other materials studied}

The other materials used were also prepared at NIBSC according to the procedures recommended by WHO(1990) and a brief description of each is given (Table 1).

Table 1. Content of ampoules used

\begin{tabular}{ll}
\hline Ampoule code & \multicolumn{1}{c}{ Assumed ampoule content } \\
\hline $86 / 690$ & $\begin{array}{l}\text { Approximately } 20 \mu \mathrm{g} \text { of inhibin from porcine follicular fluid estimated to be about } 1-3 \% \\
\text { with an assigned potency of } 2000 \text { units }\end{array}$ \\
$\begin{array}{l}\text { Coded samples } \\
\text { (A-E) }\end{array}$ & $\begin{array}{l}\text { Ampoules selected from samples of } 86 / 690 \text { stored at }-150^{\circ},-20^{\circ},+4^{\circ},+20^{\circ} \text { and }+37^{\circ} \mathrm{C} \\
87 / 534\end{array}$ \\
& $\begin{array}{l}\text { Approximately } 20 \text { 'units' (relative to oTLP units) of pure } 31 \mathrm{kDa} \text { bovine inhibin (bFF PKI } \\
\text { ampouled with } 1 \mathrm{mg} \text { human serum albumin and } 5 \mathrm{mg} \text { trehalose }\end{array}$ \\
$87 / 546$ & $\begin{array}{l}\text { Approximately } 100 \mu \mathrm{l} \text { of charcoal-treated human follicular fluid (hFF VC) ampouled with } \\
1 \text { mg human albumin and } 5 \mathrm{mg} \text { trehalose }\end{array}$ \\
$87 / 596$ & $\begin{array}{l}\text { Approximately } 20 \text { 'units' (assuming } 1 \text { unit }=1 \mathrm{mg} \text { protein) of ovine rete testis fluid prote } \\
\text { ampouled with } 1 \mathrm{mg} \text { human albumin and } 5 \mathrm{mg} \text { trehalose. }\end{array}$ \\
$87 / 716$ & $\begin{array}{l}\text { Approximately } 10 \text { 'units' of highly purified human inhibin (HPLC grade) prepared from } \\
\text { human follicular fluid }{ }^{\mathrm{b}} \text { ampouled with } 250 \mu \mathrm{g} \text { human albumin and } 2 \mathrm{mg} \text { trehalose }\end{array}$
\end{tabular}

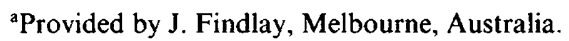

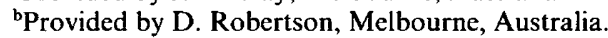

oTLP: Ovine testicular lymph protein.

All samples of human origin were tested and found negative for hepatitis B antigen and for antibody to human immunodeficiency virus.

In addition, workers at seven laboratories included their own laboratory working standard(s) in their assays. These local standards were derived from rat Sertoli cell conditioned medium, partially purified porcine follicular fluid, ovine follicular fluid and bovine follicular fluid.

\section{Participants and design of the study}

Ten participants in eight countries took part in the study (Table 2). Throughout this report, each laboratory is identified by a number from 1 to 10 , not related to the order of listing.

There was insufficient material for in vivo studies and the immunoassay phase of the study was deferred until recombinant human inhibin becomes available in sufficient quantity for study as a possible International Standard. Subject to these constraints, participants were asked to carry out their usual in vitro bioassay procedure, to use freshly reconstituted ampoules and to use sufficient replicates at multiple doses to provide data for analysis of variance and assessment of linearity and parallelism. Participants were requested to include in each assay one of each of the samples provided. However, restrictions on the available number of ampoules of some of the preparations together with 
Table 2. Participants in the study of an international standard for inhibin (in alphabetical order by country)

Dr D. Robertson, Ms Lisa Clarke and Ms Janet Jacobsen, Dept of Anatomy, Monash University, Clayton, Victoria 3168, Australia.

Dr C. G. Tsonis, Biotech Australia Pty Ltd, 28 Barcoo Street, Roseville, NSW 2069, Australia.

Dr P. Franchimont, RIA Laboratory, Institute of Pathology B23, University of Liege, B-4000 Liege, Belgium.

Professor E. Nieschlag and Dr U. Fingscheidt, Max-Planck-Gesellschaft Reproduktionsmedizin, Steinfurter Strasse 107, D-4400 Munster, Germany.

Dr A. R. Sheth and Dr K. S. Hurkaldi, Institute for Research in Reproduction, Jahangir Merwanji Street Parel, Bombay 40012, India.

Dr K. Miyamoto, Dept Obstetrics and Gynaecology, Gunma University Medical School, Maebashi, Gunma 371, Japan.

Dr S. Sasamoto, Laboratory of Veterinary Physiology, Tokyo University of Agriculture and Technology, Fuchu, Tokyo 183, Japan.

Dr F. H. de Jong, Dept of Biochemistry II, Erasmus University Rotterdam, PO Box 1738, 3000 DR Rotterdam, Netherlands.

Dr A. Steinberger, Dept Obstetrics, Gynecology and Reproductive Sciences, University of Texas Medical School, 6431 Fannin, Suite 3.212, Houston, TX 77030, USA.

Professor D. T. Baird, Dept of Obstetrics and Gynaecology, University of Edinburgh, Centre for Reproductive Biology, 37 Chalmers Street, Edinburgh EH3 9EW, UK.

limitations on the number of preparations that could be included in a single assay by the participants meant that not all preparations were assayed by all participants, who were asked to provide the raw data for centralized analysis at NIBSC and their own calculated or computed results for comparison of potency estimates.

\section{Assay methods}

Six of the ten participating laboratories used an in vitro bioassay based on dispersed anterior pituitary cells from adult (130-150 days old) male rats (de Jong et al., 1979; Franchimont et al., 1979; Scott et al., 1980; Miyamoto et al., 1985), one used female rats (Sasamoto et al., 1987), one used young (18-20 days old) male rats (Steinberger \& Steinberger, 1976), one had a short-term ( $1 \mathrm{~h}$ preincubation, $4 \mathrm{~h}$ incubation with inhibin) culture of whole pituitary glands from rats (Sheth, 1987) and one laboratory used dispersed anterior pituitary cells from young adult female sheep (Tsonis et al., 1986). Two of the participants using rat dispersed anterior pituitary cell systems carried out preincubation for 12-18 h followed by $72 \mathrm{~h}$ with test substances, and the rest used preincubation for 48 or $72 \mathrm{~h}$ followed by a similar period of incubation with test substances. With two exceptions, who used $1 \mathrm{ml}$ or $2 \mathrm{ml}$ of culture in Petri dishes, all participants dispersed their dissociated pituitary cells into 24-, 48- or 96-well plates. The number of (viable) cells per culture ranged from $4 \times 10^{4}$ to $4 \times 10^{5}$. Details of supplements, particularly the addition of homologous or heterologous or fetal serum or a mixture of sera to the culture medium (usually Dulbecco's Modified Eagles Essential Medium) varied from one laboratory to another; one used serum-free culture. The majority of participants prepared the porcine inhibin research standard 86/690 at a maximum dose of 100-200 units ml $\mathrm{mi}^{-1}$ with up to 12 serial dilutions. The actual volume added to the cultured cells ranged from 5 to $100 \mu \mathrm{l}$ giving doses of $1 \mu \mathrm{l}$ per culture for sheep cells and 2-250 $\mu \mathrm{l}$ per culture for rat cells. The majority of participants assessed the inhibitory effect of inhibins on the release of FSH from cells into the culture medium, but one used the cell content of FSH and one provided additional data from an FSH secretory system stimulated by luteinizing-hormone-releasing hormone (LHRH). Participants using rat pituitary cells measured FSH with reagents obtained from NIAMMD or as described elsewhere (Welschen et al., 1975); ovine FSH was measured according to a published method (McNeilly et al., 1976).

Each participant contributed data for two independent (i.e. using freshly reconstituted ampoules) in vitro bioassays (except laboratory 6, one assay only, and laboratory 8 , a third assay using previously made up samples). In addition, laboratory 2 carried out two further assays based on inhibition of LHRH-stimulated secretion of FSH.

Given the practical constraints of working under sterile conditions, at $37^{\circ} \mathrm{C}$, and the need for a specific gaseous phase $\left(5 \% \mathrm{CO}_{2}\right.$ in air) to maintain the $\mathrm{pH}$ of the medium, it was evident that participants followed a sequential addition of doses and preparations rather than a randomized design. Participants who reported assay design information included control wells (no inhibin) and in some cases an internal quality control on each plate.

\section{Statistical analysis}

Response data for analysis were derived from immunoassay of FSH and were taken to be either the raw counts (corrected for 'control' counts as appropriate, laboratories $2,4,8$ ) or the measured FSH concentration in $\mathrm{ng} \mathrm{ml}^{-1}$ (counts not being reported) in laboratories $1,3,5,6,9$ and 10 . Variation due to method of calculation was minimized by treating data from all laboratories in as uniform a manner as possible.

All FSH response data were plotted against log dose of inhibin and assessed visually for outliers and conformity to a consistently increasing or decreasing dose-response relationship. Data were then assessed statistically for outliers 
and homogeneity of variances (using the program SCAN, Gaines Das \& Rice, 1985). Individual responses that were detected as statistical outliers within the particular dose level and that also increased the variance of the particular group so that they made a significant contribution to the heterogeneity $\chi^{2}$ were deleted. Doses having mean responses that did not differ significantly from the extreme responses obtained were also omitted from analysis.

Data from each assay were then analysed as parallel line assays using in most cases logit transformation of responses (and the program WRANL, Gaines Das \& Tydeman, 1982), and log dose-logit response relationships were assessed for linearity and parallelism. Exceptions were laboratories 2 and 5 for which untransformed responses from the most linear part of the log dose-response curve were analysed as parallel line assays. Differences in results for the duplicate preparations, namely porcine inhibin $86 / 690$ and its coded duplicate $\mathrm{C}$, were also used to assess the intra-assay variability.

Analyses of estimated relative activities or potencies were carried out using logarithms of the estimates. Estimates were combined as geometric means with confidence intervals about the mean determined from the variance of the logarithms of the estimates combined. Inter- and intra-assay variabilities have been expressed as mean sums of squares of natural logarithms of estimates. This provides a measure of the magnitude of the variability for different comparisons.

\section{Results}

\section{Log dose-response relationships}

In a few cases, the dose-response lines (Table 3) were subject to variation which, for some preparations, gave rise to statistically significant, but apparently erratic, deviations from linearity or parallelism. This was not consistent between assays and may have resulted from the essentially non-random nature of the assay designs and from the vulnerability of these assay responses to various factors that cannot always be readily controlled. The slopes for the degradation samples $\mathrm{C}$, E, $A$ and $D$ do not show any trends and the difference between slopes for 86/690 and the samples stored at higher temperatures $\left(\mathrm{E}\left(+4^{\circ}\right), \mathrm{A}\left(+20^{\circ}\right), \mathrm{D}\left(+37^{\circ}\right)\right)$ was in most cases no greater than the difference between slopes of $86 / 690$ and its coded duplicate, ampoule C. Comparison of slopes of log dose-response lines for some pairs of dissimilar inhibins (e.g. bovine inhibin, porcine inhibin, ovine rete testis fluid and human follicular fluid) showed significant differences in some laboratories, indicating that dissimilar inhibins may be distinguished from one another. However, these apparent discriminations could not be related to assay system or to specific materials.

\section{Variability of estimates}

The estimated activity of $\mathrm{C}$, identical to $86 / 690$, expressed as percent relative proportion of the activity of $86 / 690$ is shown in Table 4 and Fig. 1. This estimate was expected to be $100 \%$ independently of assay system since $86 / 690$ and $C$ are known to be identical except for code, but, although the overall mean of $108 \%$ (95\% confidence limits $91-128 \%$ ) is consistent with this, individual estimates for the in vitro bioassays vary almost fourfold, ranging from 64 to $235 \%$.

The variability of these estimates has been subdivided into two components, namely intralaboratory interassay variation and interlaboratory variation (Table 5). Moreover, the deviation of estimates of the relative activity of $\mathrm{C}$ in terms of $86 / 690$ from the expected value of $100 \%$ provides a direct measure of intra-assay variation (Table 5).

The degradation samples $\mathrm{E}\left(+4^{\circ}\right), \mathrm{A}\left(+20^{\circ}\right)$ and $\mathrm{D}\left(+37^{\circ}\right)$ would be equivalent to $\mathrm{C}$ if no temperature-induced changes had occurred in the material. If, however, exposure to higher temperatures induced changes leading to loss of activity, estimates of relative activity for these samples would be expected to decrease with increasing temperature of exposure and, in particular, the deviation of these estimates from an 'expected value' of $100 \%$ would increase. Variabilities of estimates for $\mathrm{E}\left(+4^{\circ}\right), \mathrm{A}\left(+20^{\circ}\right)$ and $\mathrm{D}\left(+37^{\circ}\right)$ were calculated in the same way as those for $\mathrm{C}$ (Table 5). Deviations from $100 \%$ for estimates of the relative activity of $A\left(+20^{\circ}\right)$ in terms of $86 / 690$ or $C$ were substantially less than for $E\left(+4^{\circ}\right)$ and somewhat less than for $C$. Intralaboratory interassay variations were generally similar, although estimates for $\mathrm{A}\left(+20^{\circ}\right)$ in terms of $86 / 690$ and for $\mathrm{D}\left(+37^{\circ}\right)$ in terms of $\mathrm{E}\left(+4^{\circ}\right)$ had the smallest such variation. Interlaboratory variation 
Table 3. Slopes of log dose-response lines from independent assays for the ampouled preparations

\begin{tabular}{|c|c|c|c|c|c|c|c|c|c|}
\hline $\begin{array}{l}\text { Lab } \\
\text { and }\end{array}$ & $\begin{array}{l}\text { tory } \\
\text { say }\end{array}$ & $86 / 690$ & $\begin{array}{c}\mathrm{C} \\
86 / 690 \\
\text { stored } \\
\text { at }-20^{\circ} \mathrm{C}\end{array}$ & $\begin{array}{c}\mathrm{E} \\
86 / 690 \\
\text { stored } \\
\text { at }+4^{\circ} \mathrm{C}\end{array}$ & $\begin{array}{c}\text { A } \\
86 / 690 \\
\text { stored } \\
\text { at }+20^{\circ} \mathrm{C}\end{array}$ & $\begin{array}{c}\mathrm{D} \\
86 / 690 \\
\text { stored } \\
\text { at }+37^{\circ} \mathrm{C}\end{array}$ & $\begin{array}{c}87 / 534 \\
\text { bovine } \\
\text { follicular } \\
\text { fluid }\end{array}$ & $\begin{array}{l}87 / 596 \\
\text { ovine } \\
\text { rete testis } \\
\text { fluid }\end{array}$ & $\begin{array}{l}87 / 546 \\
\text { human } \\
\text { follicular } \\
\text { fluid }\end{array}$ \\
\hline \multicolumn{10}{|c|}{ In vitro bioassays } \\
\hline \multirow[t]{2}{*}{1} & 1 & -1.43 & -1.73 & -1.62 & -1.62 & & -1.54 & -1.33 & -0.68 \\
\hline & 2 & $-1 \cdot 36$ & -1.86 & -1.68 & -1.61 & & $-1 \cdot 19$ & -0.99 & -0.84 \\
\hline \multirow[t]{2}{*}{$2^{\mathrm{a}}$} & I & 261 & 399 & 447 & 238 & 487 & 328 & 291 & 320 \\
\hline & 2 & 701 & 1213 & 1200 & 1215 & 1424 & 1450 & 1668 & 719 \\
\hline \multirow[t]{2}{*}{3} & 3 & $-2 \cdot 39$ & $-2 \cdot 51$ & $-2 \cdot 17$ & $-2 \cdot 31$ & & $-2 \cdot 62$ & $-2 \cdot 14$ & $-2 \cdot 36$ \\
\hline & 2 & $-2 \cdot 37$ & $-2 \cdot 45$ & $-2 \cdot 24$ & $-2 \cdot 16$ & & $-2 \cdot 20$ & $-2 \cdot 15$ & $-2 \cdot 36$ \\
\hline \multirow[t]{2}{*}{$4^{a}$} & 1 & 1.95 & 1.78 & 1.69 & $2 \cdot 45$ & $1 \cdot 29$ & 1.46 & $1 \cdot 43$ & 1.48 \\
\hline & 2 & $2 \cdot 14$ & 3.09 & 1.86 & $2 \cdot 31$ & $4 \cdot 80$ & $3 \cdot 46$ & $1 \cdot 33$ & $2 \cdot 41$ \\
\hline 6 & 1 & -0.77 & -0.92 & -0.79 & $-0 \cdot 72$ & -0.85 & $-1 \cdot 24$ & -0.80 & -1.07 \\
\hline \multirow[t]{3}{*}{$8^{\mathrm{a}}$} & 1 & 1.07 & 0.89 & 0.97 & $1 \cdot 12$ & 1.09 & 0.88 & $1 \cdot 14$ & 1.29 \\
\hline & 2 & $1 \cdot 30$ & $1 \cdot 14$ & 1.29 & $1 \cdot 00$ & 1.05 & 1.07 & 1.56 & $1 \cdot 12$ \\
\hline & 3 & 1.53 & 0.92 & 1.44 & $1 \cdot 22$ & 1.96 & $1 \cdot 35$ & 1.89 & \\
\hline \multirow[t]{2}{*}{9} & 1 & $-1 \cdot 23$ & -0.73 & & & & $-1 \cdot 35$ & $-1 \cdot 30$ & \\
\hline & 2 & -0.89 & -0.99 & & & & $-1 \cdot 13$ & $-2 \cdot 22$ & \\
\hline \multirow[t]{2}{*}{10} & 1 & $-2 \cdot 54$ & $-3 \cdot 17$ & & & & $-2 \cdot 28$ & -2.57 & \\
\hline & 2 & -1.55 & $-1 \cdot 31$ & & & & $-2 \cdot 00$ & $-2 \cdot 49$ & \\
\hline \multicolumn{10}{|c|}{ In vitro bioassays (stimulation with luteinizing-hormone-releasing hormone) } \\
\hline \multirow[t]{2}{*}{$2^{\mathrm{a}}$} & 1 & 264 & 142 & 347 & 193 & 265 & 421 & 302 & 304 \\
\hline & 2 & 398 & 755 & 562 & 673 & 646 & 609 & 857 & 417 \\
\hline
\end{tabular}

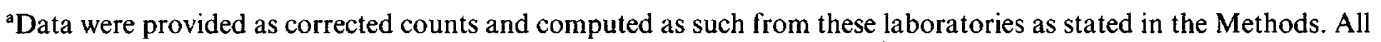
other laboratories provided data as ng follicle-stimulating hormone $\mathrm{ml}^{-1}$.

was largest for estimates of $\mathrm{D}\left(+37^{\circ}\right)$ and $\mathrm{E}\left(+4^{\circ}\right)$ in terms of $86 / 690$ and smallest for estimates of $\mathrm{C}$ and $\mathrm{A}\left(+20^{\circ}\right)$ in terms of $86 / 690$ (or $\mathrm{A}$ in terms of $\mathrm{C}$ ).

\section{Predicted stability of $86 / 690$}

Estimates of the relative activity for the thermally degraded samples E, A and D are expressed as a percentage of the activity of $\mathrm{C}$, the re-coded ampoule of $86 / 690$ stored at $-20^{\circ}$ (Table 4 and Fig. 1). Unweighted analysis of variance of the logarithms of these estimates showed a marginal difference between samples, with estimates for $\mathrm{D}\left(+37^{\circ}\right)$, in particular, showing a loss of activity and estimates for $\mathrm{E}\left(+4^{\circ}\right)$ being similar to estimates for $\mathrm{C}$; there was a tendency $(P \approx 0 \cdot 1)$ for some laboratories to detect degradation differently from others. On the basis of the overall remaining activities of $90 \%$ for $\mathrm{A}\left(+20^{\circ}\right)$ and $78 \%$ for $\mathrm{D}\left(+37^{\circ}\right)$ and using an iteratively fitted Arrhenius equation to relate relative degradation rates to temperature, the predicted yearly loss of activity at $-20^{\circ} \mathrm{C}$ is $0.9 \%$. (Relative to $86 / 690$, the remaining activities are $98 \%$ for $\mathrm{A}$ and $76 \%$ for $\mathrm{D}$, giving a predicted yearly loss at $-20^{\circ} \mathrm{C}$ of $<0.01 \%$.)

\section{Comparison of $86 / 690$ with bovine follicular fluid $87 / 534$ and various local standards derived from bovine follicular fluid}

Laboratory mean estimates of the relative activity of 'units' of $87 / 534$ lie within a sixfold range from some 4 to 23 units of $86 / 690$ equivalent to 1 unit of $87 / 534$, except for laboratory 5 which found the mean activity of $87 / 534$ relative to $86 / 690$ to be substantially less than any other laboratory (Table 6, Fig. 2). There were significant differences among estimates from the remaining laboratories. Omitting laboratories 1 (unexplained excessive intra-assay variation) and 5 , the intralaboratory mean square is 0.06 (similar to that obtained for $\mathrm{C}$ ); but the interlaboratory mean 
Table 4. Estimates of activity of coded duplicate of $86 / 690$ as percentage relative to the activity of $86 / 690$ and of $E, A$ and $D$ as percentage relative to the activity of $\mathrm{C}$

\begin{tabular}{|c|c|c|c|c|c|}
\hline Laboratory & Assay & $\begin{array}{c}\mathrm{C} \\
\text { (relative to } \\
86 / 690 \text { ) }\end{array}$ & $\begin{aligned} & E \\
+ & 4^{\circ} \mathrm{C}\end{aligned}$ & $\begin{array}{c}\mathrm{A} \\
+20^{\circ} \mathrm{C} \\
(\text { as } \% \text { of } \mathrm{C})\end{array}$ & $\begin{array}{c}\mathrm{D} \\
+37^{\circ} \mathrm{C}\end{array}$ \\
\hline \multicolumn{6}{|c|}{ In vitro bioassays } \\
\hline \multirow{2}{*}{1} & 1 & 235 & 117 & 65 & \\
\hline & 2 & 175 & 161 & 98 & \\
\hline \multirow[t]{2}{*}{2} & 2 & 137 & 200 & 62 & 173 \\
\hline & 2 & 109 & 144 & 96 & 100 \\
\hline \multirow[t]{2}{*}{3} & 1 & 93 & 109 & 97 & \\
\hline & 2 & 111 & 102 & 60 & \\
\hline \multirow[t]{2}{*}{4} & 1 & 64 & 173 & 135 & 81 \\
\hline & 2 & 103 & 87 & 86 & 40 \\
\hline 6 & 1 & 83 & 61 & 84 & 77 \\
\hline \multirow[t]{2}{*}{7} & 1 & 121 & 116 & 89 & 46 \\
\hline & 2 & 80 & 153 & 89 & 73 \\
\hline \multirow[t]{3}{*}{8} & 1 & 115 & 66 & 98 & 66 \\
\hline & 2 & 138 & 81 & 85 & 63 \\
\hline & 3 & 64 & 98 & 162 & 130 \\
\hline \multirow[t]{2}{*}{9} & 1 & 69 & & & \\
\hline & 2 & 113 & & & \\
\hline \multirow[t]{2}{*}{10} & 1 & 137 & & & \\
\hline & 2 & 112 & & & \\
\hline \multicolumn{2}{|c|}{ Geometric mean } & 108 & 112 & 90 & 78 \\
\hline \multicolumn{2}{|c|}{$95 \%$ Confidence interval } & $91-128$ & $91-138$ & $77-105$ & $57-106$ \\
\hline \multicolumn{6}{|c|}{ In vitro bioassays (stimulation with luteinizing-hormone-releasing hormone) } \\
\hline \multirow[t]{2}{*}{2} & 1 & 114 & 87 & 39 & 70 \\
\hline & 2 & 98 & 160 & 105 & 114 \\
\hline
\end{tabular}

square is 0.79 (substantially larger than that obtained for $\mathrm{C}$ ). There is no obvious difference in assay systems to account for the differences.

Five of the laboratories included local standards calibrated in 'units' of which four were specifically identified as derived from bovine follicular fluid. Estimates for these, in terms of units of $86 / 690$ equivalent to 1 'unit' of in house standard, were reasonably consistent with estimates for $87 / 534$ (Table 6).

Comparison of 86/690 with ovine rete testis fluid (87/596) and the various human preparations (87/546 and 87/716)

For any one of these materials, the estimates (Table 6, Fig. 2) had an intralaboratory variance similar to that obtained for the comparison of $\mathrm{C}$ with $86 / 690$, but the interlaboratory variance was larger than that obtained for $C$ (interlaboratory mean squares of some 0.4 ) and there were significant differences among estimates from the different laboratories. These differences did not appear to be related to the obvious differences among the assay systems (Fig. 2).

\section{Discussion}

All laboratories confirmed the biological activity of the research standard of porcine inhibin, $86 / 690$, which has been used as the reference standard for this collaborative study with its previously adopted potency of 2000 units per ampoule.

The coded duplicate of $86 / 690$, ampoule C, gave an overall mean of $108 \%$ of the activity of $86 / 690$ in good agreement with its expected value of $100 \%$, although individual estimates varied 


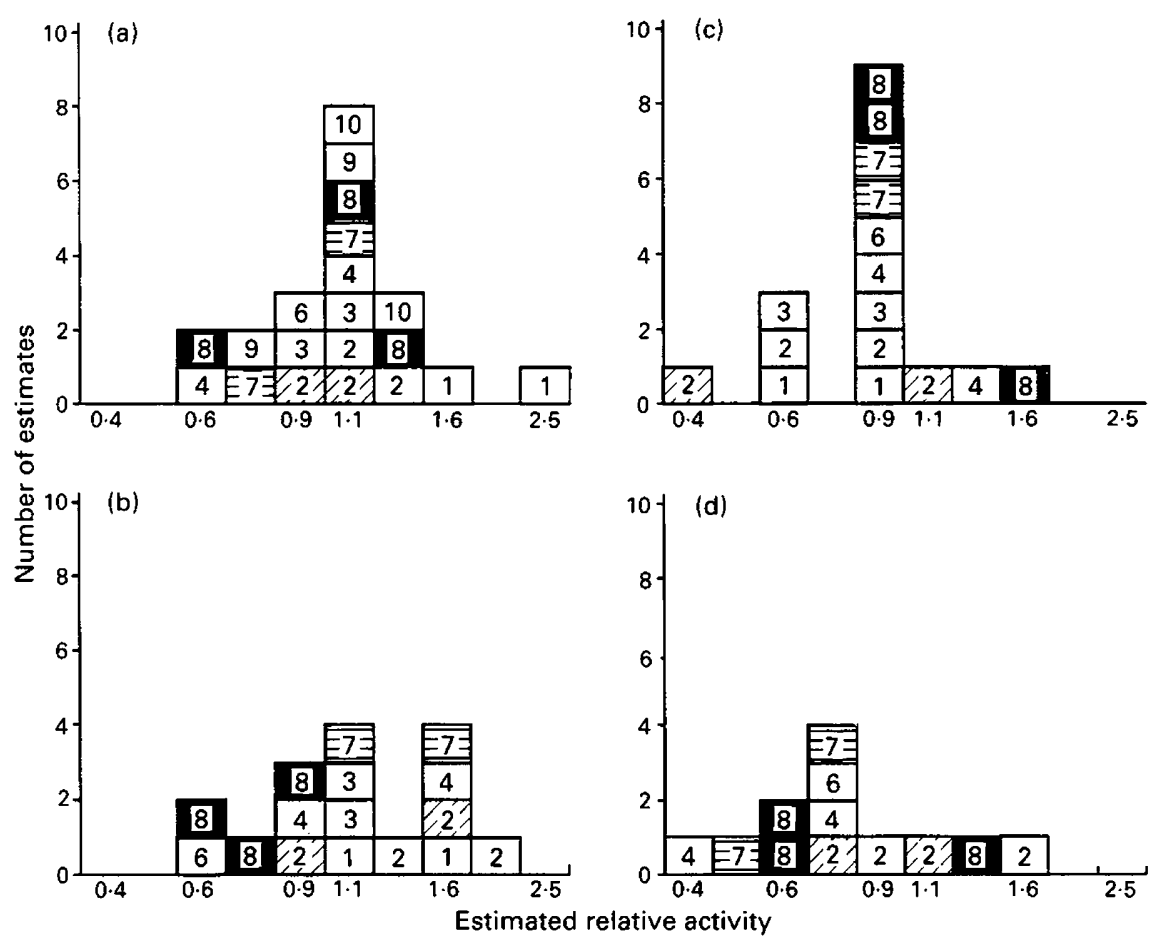

Fig. 1. Histograms showing the estimated relative activity of (a) the sample of porcine inhibin coded $C$, the coded duplicate of $86 / 690$, relative to $86 / 690$, and the samples (b) coded $\mathrm{E}$, stored for 15 months at $+4^{\circ} \mathrm{C}$, (c) coded $\mathrm{A}$, stored 15 months at $+20^{\circ} \mathrm{C}$, and (d) coded $\mathrm{D}$, stored 15 months at $+37^{\circ} \mathrm{C}$, relative to $\mathrm{C}$. Each square represents one estimate and the number in the square is the laboratory code; estimates based on $(\nabla)$ production of follicle-stimulating hormone (FSH) stimulated by luteinizing-hormone-releasing hormone, ( $\square$ ) inhibition of release of FSH from rat pituitary cells or (目) sheep pituitary cells and ( $\mathbf{0})$ cell content of FSH.

Table 5. Variability of estimates (shown as mean sums of squares of natural logarithms of estimates) of the activity of the degradation samples of $86 / 690$ stored at various temperatures relative to $86 / 690$ and to one another

\begin{tabular}{|c|c|c|c|c|c|c|c|c|c|}
\hline \multirow{4}{*}{$\begin{array}{l}\text { Temperature }\left({ }^{\circ} \mathrm{C}\right) \\
\text { Samples coded }\end{array}$} & \multicolumn{9}{|c|}{ Variability of estimates of activity relative to } \\
\hline & \multicolumn{4}{|c|}{$86 / 690$} & \multicolumn{3}{|c|}{$\mathrm{C}$} & \multicolumn{2}{|c|}{$\mathrm{E}$} \\
\hline & $(-20)$ & $(+4)$ & $(+20)$ & $(+37)$ & $(-4)$ & $(+20)$ & $(+37)$ & $(+20)$ & $(+37)$ \\
\hline & C & $\mathrm{E}$ & & & & A & & & $\mathrm{D}$ \\
\hline \multirow[t]{2}{*}{ Intra-assay variation ${ }^{a}$} & $0 \cdot 12$ & $0 \cdot 31$ & 0.07 & 0.29 & 0.13 & 0.08 & $0 \cdot 24$ & 0.24 & $0 \cdot 29$ \\
\hline & $0.07^{\mathrm{b}}$ & $0 \cdot 18^{\mathrm{b}}$ & $0.04^{\mathrm{b}}$ & & & & & & \\
\hline \multirow{2}{*}{$\begin{array}{l}\text { Intralaboratory } \\
\text { interassay variation }\end{array}$} & 0.08 & 0.05 & 0.02 & 0.07 & 0.07 & 0.09 & $0 \cdot 17$ & 0.08 & 0.04 \\
\hline & $0.09^{\mathrm{b}}$ & $0.06^{b}$ & $0.03^{b}$ & & & & & & \\
\hline \multirow{2}{*}{$\begin{array}{l}\text { Interlaboratory } \\
\text { variation }\end{array}$} & $0 \cdot 15$ & 0.56 & $0 \cdot 14$ & 0.46 & $0 \cdot 20$ & 0.05 & $0 \cdot 23$ & 0.25 & $0 \cdot 29$ \\
\hline & $0.05^{\mathrm{b}}$ & $0 \cdot 35^{\mathrm{b}}$ & $0 \cdot 05^{\mathrm{b}}$ & & & & & & \\
\hline \multirow{2}{*}{$\begin{array}{l}\text { Number of laboratory } \\
\text { estimates }\end{array}$} & 9 & 7 & 7 & 5 & 7 & 7 & 5 & 7 & 5 \\
\hline & $8^{\mathrm{b}}$ & $6^{\mathrm{b}}$ & $6^{\mathrm{b}}$ & & & & & & \\
\hline
\end{tabular}

${ }^{a}$ Based on deviations from a relative activity of 1 , i.e. assuming no degradation for samples $E, A$ and $D$.

bomitting estimates from laboratory 1 . 
Table 6. Estimates of the relative activity of bovine follicular fluid coded $87 / 534$, ovine rete testis fluid coded $87 / 596$ and purified human inhibin coded $87 / 716$, and of the various local standards comprising bovine follicular fluid calibrated in 'units' (column headed L) as equivalent units of $86 / 690$ per unit and of human follicular fluid coded $87 / 546$ as equivalent units of $86 / 690 \mu 1^{-1}$

\begin{tabular}{|c|c|c|c|c|c|c|}
\hline Laboratory & Assay & $87 / 534$ & $87 / 596$ & $87 / 546$ & $87 / 716$ & $\mathbf{L}$ \\
\hline \multicolumn{7}{|c|}{ In vitro bioassays } \\
\hline \multirow[t]{2}{*}{1} & 1 & 8.92 & 8.99 & $4 \cdot 16^{\mathrm{a}}$ & & \\
\hline & 2 & $16 \cdot 69$ & $20 \cdot 94$ & $26 \cdot 10^{\mathrm{a}}$ & NA & NA \\
\hline \multirow[t]{2}{*}{2} & 1 & $16 \cdot 41$ & $28 \cdot 82$ & $1 \cdot 50$ & $351^{a}$ & $4.94^{\mathrm{ab}}$ \\
\hline & 2 & $27 \cdot 53$ & $24 \cdot 39$ & $1 \cdot 13$ & $773^{a}$ & $3 \cdot 88^{\mathrm{ab}}$ \\
\hline \multirow[t]{2}{*}{3} & 1 & $8 \cdot 50$ & 17.93 & 0.96 & & \\
\hline & 2 & $11 \cdot 89$ & $23 \cdot 09$ & $1 \cdot 10$ & NA & NA \\
\hline \multirow[t]{2}{*}{4} & 1 & $5 \cdot 11$ & $17 \cdot 15$ & 0.76 & & 7.61 \\
\hline & 2 & $4 \cdot 63$ & 12.73 & 0.52 & NA & \\
\hline \multirow[t]{2}{*}{5} & 1 & $0 \cdot 85^{\mathrm{a}}$ & & & & \\
\hline & & $0.52^{\mathrm{a}}$ & NA & NA & NA & NA \\
\hline 6 & 1 & $6 \cdot 59$ & 23.97 & 1.25 & NA & $7 \cdot 14$ \\
\hline \multirow[t]{2}{*}{7} & 1 & $6 \cdot 58$ & $14 \cdot 01$ & 0.54 & $4 \cdot 39$ & $12 \cdot 91$ \\
\hline & 2 & $7 \cdot 22$ & 11.53 & $0 \cdot 42$ & 4.05 & $12 \cdot 67$ \\
\hline \multirow[t]{3}{*}{8} & 1 & 8.72 & $20 \cdot 23$ & $1 \cdot 08$ & $6 \cdot 53$ & $12 \cdot 63$ \\
\hline & 2 & $11 \cdot 41$ & $33 \cdot 33$ & 1.91 & $7 \cdot 58$ & $10 \cdot 51$ \\
\hline & 3 & $9 \cdot 85$ & $25 \cdot 41$ & & & $23 \cdot 35$ \\
\hline \multirow[t]{2}{*}{9} & 1 & $5 \cdot 89$ & $9 \cdot 37$ & & & 6.55 \\
\hline & 2 & $2 \cdot 85$ & $7 \cdot 00$ & NA & NA & $4 \cdot 50$ \\
\hline \multirow[t]{2}{*}{10} & 1 & $23 \cdot 11$ & $42 \cdot 75$ & & & \\
\hline & 2 & $23 \cdot 13$ & $29 \cdot 28$ & NA & NA & \\
\hline \multicolumn{2}{|c|}{ Geometric mean } & $9 \cdot 56$ & $18 \cdot 51$ & $0 \cdot 92$ & $5 \cdot 45$ & $9 \cdot 76$ \\
\hline \multirow{2}{*}{\multicolumn{2}{|c|}{$95 \%$ Confidence limits }} & $7 \cdot 05$ & $14 \cdot 48$ & 0.67 & $3 \cdot 36$ & $6 \cdot 72$ \\
\hline & & $-12 \cdot 96$ & $-23 \cdot 60$ & $-1 \cdot 27$ & $-8 \cdot 82$ & $-14 \cdot 20$ \\
\hline \multicolumn{7}{|c|}{ In vitro bioassays (stimulation with luteinizing-hormone-releasing hormone) } \\
\hline 1 & 2 & 5.87 & 16.57 & $0 \cdot 68$ & 128 & $1 \cdot 71^{\mathrm{b}}$ \\
\hline 2 & 2 & $25 \cdot 79$ & $27 \cdot 10$ & $1 \cdot 55$ & 965 & $2 \cdot 66^{\mathrm{b}}$ \\
\hline
\end{tabular}

${ }^{\mathrm{a}}$ Omitted from calculation of geometric mean.

'Units of $86 / 690 \mu \mathrm{g}^{-1}$ local standard.

NA, not assayed.

almost fourfold (64-235\%). In an attempt to elucidate the sources of this variation, the variabilities of estimates for each of the degradation samples of $86 / 690$, and in particular that for $E$ (stored at $+4^{\circ} \mathrm{C}$ and showing no evidence of change in relative activity), were compared. In previous studies such as this (e.g. Gaines Das \& Bristow, 1985) the intra-assay and interlaboratory variation of estimates for the degradation samples have shown a tendency to increase with increasing degradation, reflecting both loss of activity and the different specificity with which degraded materials are detected in different assay systems. However, in these assay systems both the intra-assay and interlaboratory variation, notably for estimates in terms of $86 / 690$ for samples $\mathrm{E}\left(+4^{\circ}\right)$ and $\mathrm{A}$ $\left(+20^{\circ}\right)$ (Table 5), appear to relate more closely to the order in which the preparation was positioned in the assay, i.e. in alphabetical sequence A-E, than to degree of possible degradation. Estimates for sample D $\left(+37^{\circ}\right)$ showed evidence both of loss of activity and of the expected resultant increase in variability if variability for $\mathrm{D}\left(+37^{\circ}\right)$ was compared with that for $\mathrm{C}\left(-20^{\circ}\right)$ or A $\left(+20^{\circ}\right)$, but less so if the variability was compared with that for $E\left(+4^{\circ}\right)$. The finding that intralaboratory interassay variation is smallest for estimates of activity of materials in terms of 'adjacent' materials, i.e. $A\left(+20^{\circ}\right)$ in terms of $86 / 690$ and $\mathrm{D}\left(+37^{\circ}\right)$ in terms of $\mathrm{E}\left(+4^{\circ}\right)$, is also consistent with dependence of estimates on assay position. This suggests that the estimates obtained in these assay systems may be substantially influenced by the assay design in conjunction with the vulnerability of these systems to factors that cannot readily be controlled. 


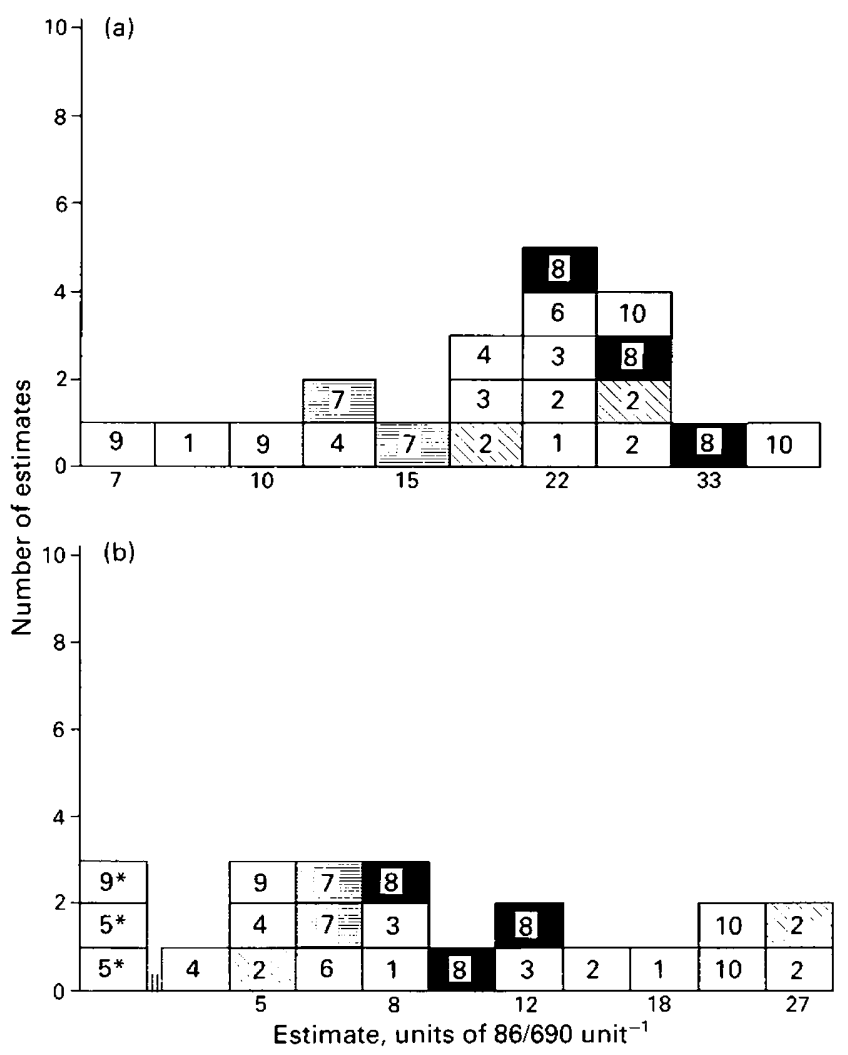

Fig. 2. Histograms showing the estimated relative potencies of samples coded (a) $87 / 596$ and (b) $87 / 534$ expressed as units of $86 / 690$ per unit of sample. Each square represents one estimate and the number in the square is the laboratory code; numbers marked * are not plotted to scale, but have been plotted as shown for information; actual values are given in Table 5; estimates based on ( $\mathbb{\nabla})$ luteinizing-hormone-releasing hormone-stimulated follicle-stimulating hormone (FSH) production, $(\square)$ inhibition of release of FSH from rat or $($ 目) sheep pituitary cells and ( $\square$ ) cell content of FSH.

It is hoped that recognition of the inherent variation of established in vitro pituitary cell assays, as shown by the results obtained by this collaborative study, will lead to improved control of sources of within-assay variation.

In view of the variability of estimates within assays and the indications from the data that such degradation as has occurred may not be equally detectable in all assay systems, no precise prediction of stability can be made. However, predictions based on 'consensus' estimates suggest that little loss of activity at $-20^{\circ} \mathrm{C}$ is likely to occur. Estimates for samples stored for 15 months at $+4^{\circ} \mathrm{C}$ are indistinguishable from estimates for samples stored continuously at $-20^{\circ} \mathrm{C}$, providing further confirmation of satisfactory stability.

Given the inherent almost four-fold variation for comparisons of identical materials and the apparent influence of assay design on the results of these comparisons, the comparisons of 'unlike' substances, which varied with a three- to sixfold range cannot readily be interpreted. It is certainly likely that the variation observed for comparisons of unlike substances, particularly those which are not highly purified, may be due to the presence of other bioactive entities such as activin (although this seems unlikely as discussed earlier) or of follistatins (Ueno et al., 1987) as well as to differences in assay systems (as discussed by Robertson et al., (1986, 1990). However, despite the cautions that need to be considered when interpreting the results of pituitary cell assays, the fact 
remains that progress on the biological activity of inhibin (and activin and follistatin) and insight into its physiology have depended on such bioassay systems (de Kretser, 1990).

On the basis of this collaborative study, together with comments from participants and experience of the use of the research standard for porcine inhibin, the WHO ECBS established the preparation in ampoules coded $86 / 690$ as the first International Standard for porcine inhibin (WHO ECBS, 1991). The assigned potency of 2000 International Units per ampoule maintains continuity with the potency originally adopted for its research use in pituitary cell bioassays. The standard is available in limited quantity from NIBSC - a handling charge is levied.

Although the international availability of a single stable bioassay research standard has played a key role since 1987 for many investigators using pituitary cell bioassays to assess biological materials containing inhibin, it is now evident that research emphasis has moved to the clinical field and the development and application of immunoassays (e.g. Knight et al., 1991). The requirement for a reference standard of highly purified inhibin has awaited the availability of recombinant human inhibin as amounts obtainable from natural sources are insufficient for use as an international standard. The cloning of human inhibin was achieved in 1986 (Mason et al.), but only recently has the reliable production of a well characterized recombinant glycoprotein reached commercial viability. Two batches of recombinant human inhibin have been generously donated by their manufacturers to WHO as candidate international standards. Their assessment by international collaborative study, to include both bioassay and immunoassay, is now ongoing as the next phase in the standardization of inhibins.

Grateful acknowledgements are due to W. L. Gordon and his colleagues (Houston, TX, USA) for isolation and characterization of the bulk material and preliminary assessment of the ampouled material; the Contraceptive Development Branch of the NIH, USA, for making the material for the standard available, through G. Bialy; to J. K. Findlay, G. M. H. Waites (WHO Special Programme of Research, Development and Research Training in Human Reproduction); to F. H. de Jong (Rotterdam) and D. M. Robertson (Melbourne) for preliminary comparisons of the bulk and standard and helpful discussions of this manuscript; to P. L. Storring (NIBSC) for coordination of the initial phases of the study and to P. K. Phillips and staff of the Standards Processing Department (NIBSC) for ampouling. Grateful acknowledgements are also due to all the participants in the international collaborative study.

\section{References}

Caygill, P.J.C. (1977) Detection of peptidase activity in albumin preparations. Clinica Chimica Acta 78, $507-509$.

de Jong F.H., Smith, D.S. \& van der Molen, H.J. (1979) Bioassay of inhibin-like activity using pituitary cells in vitro. Journal of Endocrinology 80, 91-102.

de Jong, F.H., Grootenhius, A.J., Klaij, I.A. \& Van Beurden, W.M. (1990) Inhibin and related proteins: localization, regulation and effects. Advances in Experimental Medicine and Biology 274, 271-293.

de Kretser, D.M. (1990) At the cutting edge - inhibin. Molecular and Cellular Endocrinology 69, C17-C20.

Forage, R.G., Ring, J.M., Brown, R.W., McInerney, R.W., Cobon, G.S., Gregson, R.P., Robertson, D.M., Morgan, F.J., Hearn, M.T.W., Findlay, J.K., Wettenhall, R.E.H., Burger, H.G. \& de Kretser, D.M. (1986) Cloning and sequence analysis of cDNA species coding for the two subunits of inhibin from bovine follicular fluid. Proceedings of the National Academy of Sciences USA 83, 3091-3095.
Franchimont, P.J., Demoulin, A., Verstraelen-Proyard, J., Hazee-Hagelstein, M.T. \& Tunbridge, W.M.G. (1979) Identification in human seminal fluid of an inhibin-like factor which selectively regulates FSH secretion. Journal of Reproduction and Fertility Supplement 26, 123-133.

Gaines Das, R.E. \& Bristow, A.F. (1985) The second international reference preparation of thyroid-stimulating hormone, for immunoassay: calibration by bioassay and immunoassay in an international collaborative study. Journal of Endocrinology 104, 367-379.

Gaines Das, R.E. \& Rice, L.R. (1985) SCAN, an exploratory program for preliminary analysis of bioassay and immunoassay data. Computer Methods and Programs in Biomedicine 21, 25-33.

Gaines Das, R.E. \& Tydeman, M.S. (1982) Iterative weighted regression analysis of logit responses. A computer program for analysis of bioassays and immunoassays. Computer Methods and Programs in Biomedicine 15, 13-22. 
Gordon, W.L., Liu, W-K. \& Ward, D.N. (1986) Inhibin fractionation: a comparison of human and porcine follicular fluid, with particular reference to protease activation. Biology of Reproduction 35, 209-218.

Knight, P.G., Groome, N. \& Beard, A.J. (1991) Development of a two-site immunoradiometric assay for dimeric inhibin using antibodies against chemically synthesized fragments of the $\alpha$ and $\beta$ sub-unit. Journal of Endocrinology 129, R9-R12.

Ling, N., DePaulo, L.V., Bicsak, T.A. \& Shimasaki, S. (1990) Novel ovarian regulatory peptides: inhibin, activin and follistatin. Clinical Obstetrics and Gynecology 33, 690-702.

McCullagh, D.R. (1932) Dual endocrine activity of the testes. Science 76, 19-20.

McNeilly, J.R., McNeilly, A.S., Walton, J.S. \& Cunningham, F.J. (1976) Development and application of a heterologous radioimmunoassay for ovine follicle stimulating hormone. Journal of Endocrinology 70, 69-79.

Mason, A.J., Niall, H.D. \& Seeburg, P.H. (1986) Structure of two human ovarian inhibins. Biochemical and Biophysical Research Communications 135, 957-964.

Miyamoto, K., Hasegawa, Y., Fukuda, M., Nomura, M., Igarashi, M., Kanggawa, K. \& Matsuo, H. (1985) Isolation of porcine follicle fluid inhibition of $32 \mathrm{~K}$ daltons. Biochemical and Biophysical Research Communications 129, 396-403.

Risbridger, G.P., Robertson, D.M. \& de Kretser, D.M. (1990) Current perspectives of inhibin biology. Acta Endocrinologica 122, 673682.

Robertson, D.M., Foulds, L.M., Leversha, L., Morgan, F.J., Hearn, M.T.W., Burger, R.E.H., Wettenhall, R.E.H. \& de Kretser, D.M. (1985) Isolation of inhibin from bovine follicular fluid. Biochemical and Biophysical Research Communications 126, 220-226.

Robertson, D.M., Giacometti M.S. \& de Kretser, D.M. (1986) The effects of inhibin purified from bovine follicular fluid in several in vitro pituitary cell culture systems. Molecular and Cetlular Endocrinology 46, 29-36.

Robertson, D.M., Farnworth, P.G., Clarke, L., Jacobsen, J., Cahir, N.F., Burger, H.G. \& de Kretser, D.M. (1990) Effects of bovine $35 \mathrm{kDa}$ FSH-suppressing protein on FSH and LH in rat pituitary cells in vitro: comparison with bovine $31 \mathrm{kDa}$ inhibin. Journal of Endocrinology 124, 417-423.

Sasamoto, S., Taya, K., Arakawa, H. \& Kishi, H. (1987) Inhibin secretion and suppression of the FSH surge in superovulating animals. In Inhibin-Non-steroidal Regulation of Follicle Stimulating Hormone Secretion. Serono Symposia Publication 42, 219-232. Eds H. G.
Burger, D. M. de Kretser, J. K. Findlay \& M. Igarashi. Raven Press, New York.

Scott, R.S., Burger, H.G. \& Quigg, H. (1980) A simple and rapid in vitro assay for inhibin. Endocrinology 107, 1536-1542.

Sheth, A.R. (1987) Inhibins - Isolation, Estimation and Physiology. Clinical Research Centre Press, Boca Raton, FA USA.

Steinberger, A. \& Steinberger, E. (1976) Secretion of an FSH binding factor by cultured Sertoli cells. Endocrinology 99, 918-921.

Stewart, A.G., Milborrow, H.M., Ring, J.M., Crowther, C.E. \& Forage, R.G. (1986) Human inhibin genes: genomic characterization and sequencing. FEBS Letters 206, 329-334.

Tsonis, C.G., McNeilly, A.S. \& Baird, D.T. (1986) Measurement of exogenous and endogenous inhibin in sheep serum using a new and extremely sensitive bioassay for inhibin based on inhibition of ovine pituitary FSH secretion in vitro. Journal of Endocrinology 110, 341-352.

Ueno, N., Ling, N., Ying, S-Y., Esch, F., Shimasaki, S. \& Guillemin, R. (1987) Isolation and partial characterization of follistatin: a single-chain $M, 35,000$ monomeric protein that inhibits the release of follicle stimulating hormone. Proceedings of the National Academy of Sciences USA 84, 8282-8286.

Vale, W., Rivier, J., Vaughan, J., McClintock, R., Corrigan, A., Woo, W., Karr, D. \& Speiss, J. (1986) Purification and characterization of an FSH releasing protein from porcine ovarian follicular fluid. Nature 321, 776-779.

Waites, G.M.H., Bialy, G., Gordon, W.L., Findlay, J.K., de Jong, F.H., Robertson, D.M., Schwartz, N.B. \& Storring, P.L. (1987) International research standard for inhibin. In Inhibin - Non-steroidal Regulation of Follicle Stimulating Hormone Secretion. Serono Symposia Publication 42, 281-288. Eds H. G. Burger, D. M. de Kretser, J. K. Findlay \& M. Igarashi. Raven Press, New York.

Welschen, R., Osman, P., Dullaaert, J., de Greef, W.J., Uilenbroek, J.Th.J. \& de Jong, F.H. (1975) Levels of follicle stimulating hormone, luteinizing hormone, oestradiol-17 $\beta$ and progesterone, and follicular growth in the pseudopregnant rat. Journal of Endocrinology 64, 37-47.

World Health Organization Expert Committee on Biological Standardization (1990) WHO Technical Report Series No. 800. Annex 4, pp. 181-213.

World Health Organization Expert Committee on Biological Standardization (1991) WHO Technical Report Series. No. 814, pp 10-11.

Received 28 November 1991 